\title{
Antimicrobial Medical Textiles Used in Clinical Settings May Play an Important Role in Reducing Healthcare-Acquired Infections
}

Gadi Borkow*

Chief Medical Scientist, Cupron Scientific, Israel

*Corresponding author: Gadi Borkow, PhD, Cupron Scientific, Hasadnaot 10, Herzelia

46733, Israel, Tel: 972-54-6611287; Email: gadi@cupron.com

\section{Editorial}

Volume 3 Issue 2

Received Date: September 17, 2019

Published Date: September 20, 2019

DOI: $10.23880 /$ jidtm-16000131
Abbreviations: HAI: Healthcare-Acquired Infection; VRE: Vancomycin-Resistant Enterococci; MRSA: Methicillin-Resistant Staphylococcus aureus.

\section{Editorial}

Millions of individuals worldwide acquire a Healthcare-acquired infection (HAI) each year, making HAIs a global problem contributing significantly to mortality, morbidity, and hospitalization costs, especially as many pathogens have developed high resistance to the existent antibiotic arsenal [1]. The association between HAIs and environmental contamination within the healthcare environment is now well established [2,3]. It has become clear that contaminated surfaces contribute to the transmission of different pathogens such as Clostridium difficile, vancomycin-resistant enterococci (VRE), methicillin-resistant Staphylococcus aureus (MRSA), Acinetobacter baumannii, Pseudomonas aeruginosa and norovirus [2,4]. It has also become clear that decontamination of the contaminated surfaces contributes to the reduction of nosocomial infection outbreaks [3]. However, decontamination of contaminated surfaces is not always effective and even the effect of thorough cleaning can be short lived $[5,6]$.

Copper has potent wide spectrum biocidal properties $[7,8]$. It has been shown in several laboratory and clinical studies that the incorporation of metallic copper or copper oxide particles into inanimate surfaces, such as countertops, knobs, and handles, significantly reduces bioburden as compared to non-biocidal respective surfaces [9-18]. The biocidal activity of copper was demonstrated against an array of healthcare-associated pathogens such as Escherichia coli, Klebsiella pneumoniae, Pseudomonas aeruginosa, Staphylococcus aureus, Acinetobacter baumannii and Clostridium difficile [12,19]. Furthermore, the biocidal efficacy was also demonstrated against antibiotic resistant pathogens, such as MRSA, VRE, carbapenemase-producing Gram-negative bacteria and several multi drug resistant pathogens $[20,21]$. In two studies, the use of copper hard surfaces, such as the inanimate surfaces mentioned above, resulted in statistically significant reduction of HAI rates [22,23], while one study found that exposure of pediatric patients to copper-surfaced objects resulted in decreased HAI rates as compared to exposure to non-copper surfaces; however, the relative risk reduction did not reach statistical significance [24].

As of today, only copper alloys and polymeric surfaces containing copper oxide microparticles have received EPA approval to make public health claims (EPA registrations 85012, 1-6 and 84542-7, respectively) and thus in many hospitals metallic copper and polymeric surfaces containing copper oxide microparticles are being installed in frequently touched surfaces [25]. We and others have postulated that the immediate inanimate surfaces in direct contact with the patients play a very significant role in HAIs [26,27], more than the surfaces in indirect contact with the patients $[28,29]$. This was based on the following main observations: humans shed bacteria directly from their skin and other areas onto the textiles they use. Spillages and body exudates, such as blood, stool, urine, and other secretions, all of which can contain large amounts of bacteria that may come in direct contact with 
hospital textiles. Textiles are an excellent substrate for microbial proliferation when in contact with the human body. The moisture and temperature conditions present between the skin and the textiles and the very large surface area, provide an ideal environment for microbial proliferation. Indeed, heavy microbial colonization of sheets, patient pajamas and healthcare worker uniforms, including by antibiotic resistant bacteria, has been reported [26,28-32]. Some microorganisms remain viable on textiles, even after industrial laundry, for very prolonged periods of time, even months, under ambient temperature and humidity $[33,34]$.

The microorganisms that multiply or remain on the textiles can be a source of healthcare-acquired pathogens. These pathogens can be transmitted via endogenous route (i.e. from one part of the host's body to another), via a direct or indirect route (through surfaces in indirect contact with the patients) to other patients and hospital personnel, and via aerosol transmission [28,29,35,36].The notion that hospital linens and patient and personnel clothing play an important role in HAIs has gained recognition since then $[37,38]$. We have also hypothesized that biocidal surfaces in direct contact with the patient, such as the linen, pajamas, and robes, may play a significant role in reducing the spread of pathogens and the risk of HAI in the clinical environment by reducing bioburden [28,29]. Today many wide spectrum antimicrobial agents are introduced into medical textiles endowing the textiles with antimicrobial properties [37]. Several studies have been conducted in clinical settings with antimicrobial textiles in which their capacity to reduce bioburden and HAIs have been examined. Figure 1 summarizes the studies conducted in clinical settings with different antimicrobial medical textiles [39-43], all of which demonstrated reduction of bioburden of all or some of the microorganisms studied.

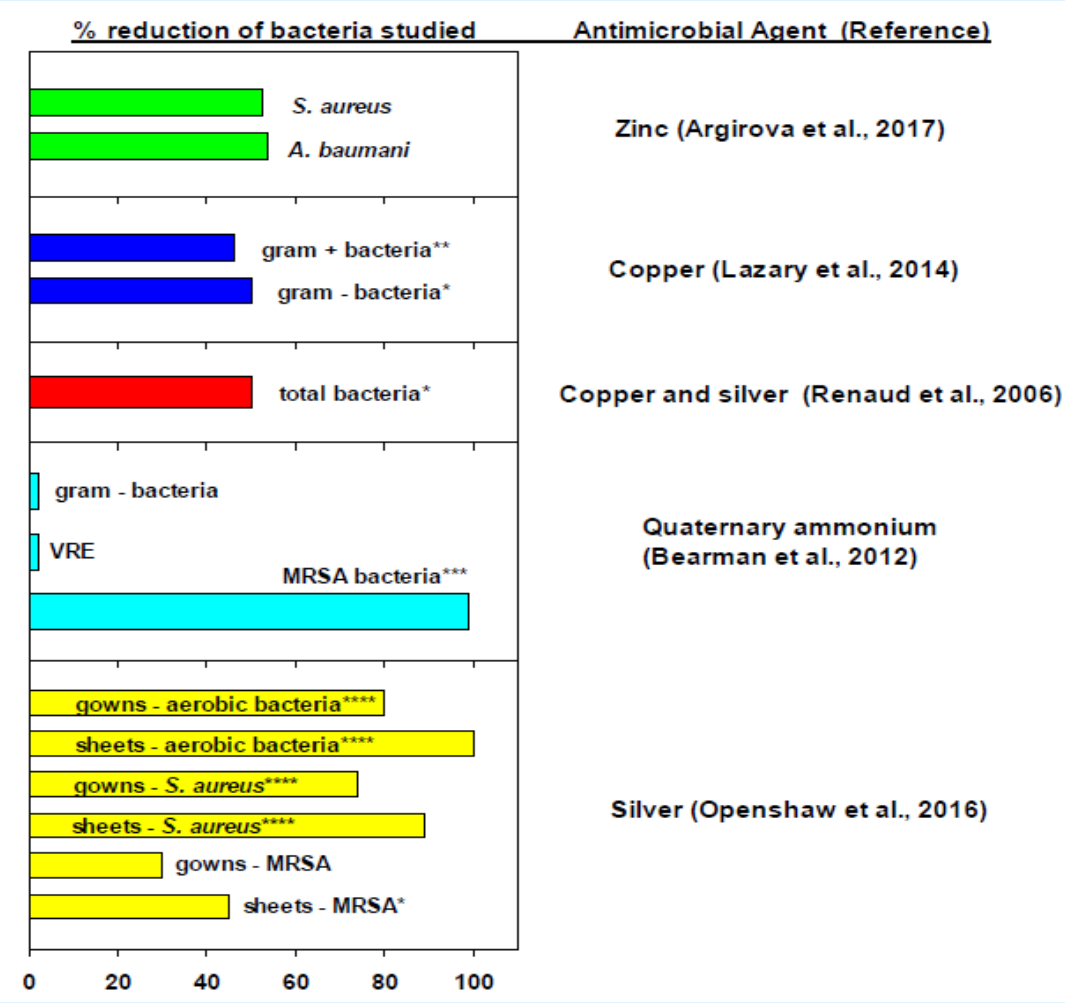

${ }^{*} \mathrm{p}<0.05 ;{ }^{* *} \mathrm{p}<0.01 ;{ }^{* * *} \mathrm{p}<0.001 ;{ }^{* * * *} \mathrm{p}<0.0001$ When there is no specification either the $\mathrm{p}$ value was not reported or there was no statistically significant difference between the arms studied.

Figure 1: Reduction of bioburden by antimicrobial medical textiles in clinical settings. 
More importantly, several studies [23,39,42,44-49] conducted with antimicrobial medical textiles (mostly medical textiles containing copper oxide), with exception of one study, demonstrated a significant reduction of HAIs in the study arm using the antimicrobial medical textiles (Figure 2).

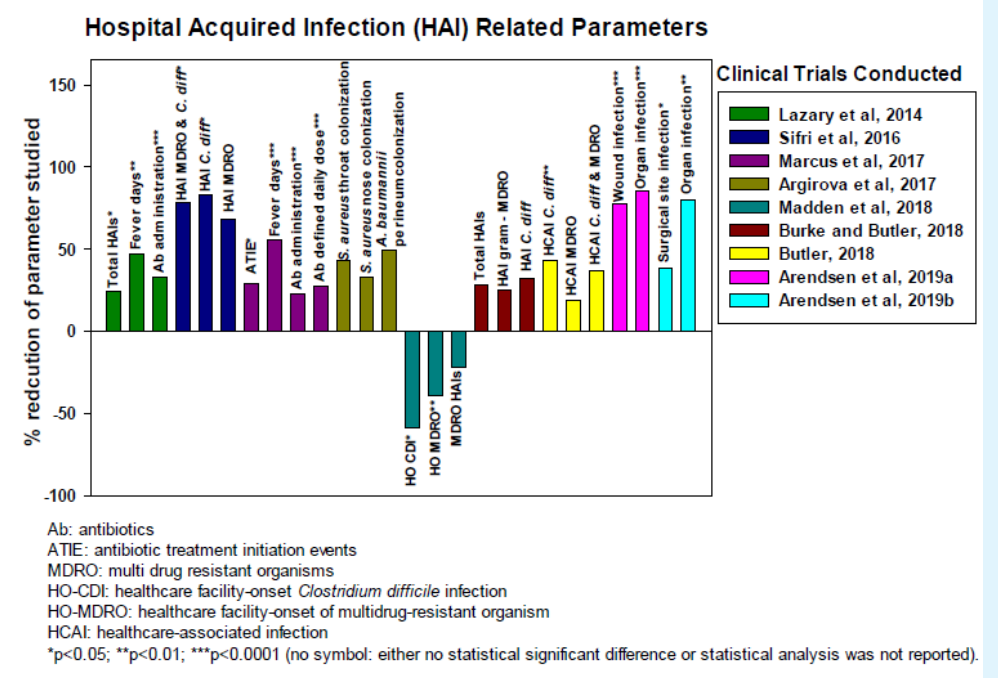

Figure 2: Reduction of HAIs by antimicrobial medical textiles.

While additional studies may be needed to better understand the effect of antimicrobial medical textiles and reduction of HAIs in different medical settings, the described studies in Figures 1 and 2 overall have given significant support to the notion that biocidal textiles used in clinical settings may be an important adjunct in the fight against HAIs.

\section{References}

1. Jones RN (2001) Resistance patterns among nosocomial pathogens: trends over the past few years. Chest 119(2): 397-404.

2. Weber DJ, Anderson D, Rutala WA (2013) The role of the surface environment in healthcare-associated infections. Curr Opin Infect Dis 26(4): 338-344.

3. Otter JA, Yezli S, French GL (2014) The role of contaminated surfaces in the transmission of nosocomial pathogens. Use of Biocidal Surfaces for Reduction of Healthcare Acquired Infections, pp: 2758.

4. Greenhalgh R, Walker JT (2017) Antimicrobial strategies for polymeric hygienic surfaces in healthcare. International Biodeterioration \& Biodegradation 125: 214-227.
5. Dancer SJ (2011) Hospital cleaning in the 21st century. Eur J ClinMicrobiol Infect Dis 30(12): 14731481.

6. Hardy KJ, Gossain S, Henderson N, Drugan C, Oppenheim BA, et al. (2007) Rapid recontamination with MRSA of the environment of an intensive care unit after decontamination with hydrogen peroxide vapour. J Hosp Infect 66(4): 360-368.

7. Borkow G, Gabbay J (2005) Copper as a biocidal tool. Curr Med Chem 12(18): 2163-2175.

8. Borkow G (2012) Using copper to fight microorganisms. Curr Chem Biol 6(2): 93-103.

9. Casey AL, Adams D, Karpanen TJ, Lambert PA, Cookson BD, et al. (2010) Role of copper in reducing hospital environment contamination. J Hosp Infect 74(1): 72-77.

10. Karpanen TJ, Casey AL, Lambert PA, Cookson BD, Nightingale $\mathrm{P}$, et al. (2012) The antimicrobial efficacy of copper alloy furnishing in the clinical environment: a crossover study. Infect Control Hosp Epidemiol 33(1): 3-9.

11. Mikolay A, Huggett S, Tikana L, Grass G, Braun J, et al. (2010) Survival of bacteria on metallic copper 


\section{Journal of Infectious Diseases \& Travel Medicine}

surfaces in a hospital trial. Appl Microbiol Biotechnol 87(5): 1875-1879.

12. Monk AB, Kanmukhla V, Trinder K, Borkow G (2014) Potent bactericidal efficacy of copper oxide impregnated non-porous solid surfaces. BMC Microbiol 14(1): 57.

13. Schmidt MG, Attaway HH, Sharpe PA, John J, Sepkowitz KA, et al. (2012) Sustained reduction of microbial burden on common hospital surfaces through introduction of copper. J Clin Microbiol 50(7): 2217-2223.

14. Schmidt MG, Attaway Iii HH, Fairey SE, Steed LL, Michels HT, et al. (2013) Copper continuously limits the concentration of bacteria resident on bed rails within the intensive care unit. Infect Control Hosp Epidemiol 34(5): 530-533.

15. Schmidt MG, Banks AL, Salgado CD (2014) Role of the microbial burden in the acquisition and control of healthcare associated infections: the utility of solid copper surfaces. Use of Biocidal Surfaces for Reduction of Healthcare Acquired Infections 4: 59-83.

16. Hinsa-Leasure SM, Nartey Q Vaverka J, Schmidt MG (2016) Copper alloy surfaces sustain terminal cleaning levels in a rural hospital. Am J Infect Control 44(11): 195-203.

17. Inkinen $\mathrm{J}$, Makinen $\mathrm{R}$, Keinanen-Toivola MM, Nordstrom K, Ahonen M (2017) Copper as an antibacterial material in different facilities. Lett Appl Microbiol 64(1): 19-26.

18. Souli M, Antoniadou A, Katsarolis I, Mavrou I, Paramythiotou E, et al. (2017) Reduction of Environmental Contamination With MultidrugResistant Bacteria by Copper-Alloy Coating of Surfaces in a Highly Endemic Setting. Infect Control Hosp Epidemiol 38(7): 765-771.

19. Weaver L, Michels HT, Keevil CW (2008) Survival of Clostridium difficile on copper and steel: futuristic options for hospital hygiene. J Hosp Infect 68(2): 145151.

20. Souli M, Galani I, Plachouras D, Panagea T, Armaganidis A, et al. (2013) Antimicrobial activity of copper surfaces against carbapenemase-producing contemporary Gram-negative clinical isolates. J Antimicrob Chemother 68(4): 852-857.

21. Weaver L, Noyce JO, Michels HT, Keevil CW (2010) Potential action of copper surfaces on meticillin- resistant Staphylococcus aureus. J Appl Microbiol 109(6): 2200-2205.

22. Salgado CD, Sepkowitz KA, John JF, Cantey JR, Attaway $\mathrm{HH}$, et al. (2013) Copper surfaces reduce the rate of healthcare-acquired infections in the intensive care unit. Infect Control Hosp Epidemiol 34(5): 479-486.

23. Sifri CD, Burke GH, Enfield KB (2016) Reduced health care-associated infections in an acute care community hospital using a combination of self-disinfecting copper-impregnated composite hard surfaces and linens. Am J Infect Control 44(12): 1565-1571.

24. von Dessauer B, Navarrete MS, Benadof D, Benavente C, Schmidt MG (2016) Potential effectiveness of copper surfaces in reducing health care-associated infection rates in a pediatric intensive and intermediate care unit: A nonrandomized controlled trial. Am J Infect Control 44(8): 133-139.

25. Coppin JD, Villamaria FC, Williams MD, Copeland LA, Zeber JE, et al. (2017) Self-sanitizing copperimpregnated surfaces for bioburden reduction in patient rooms. Am J Infect Control 45(6): 692-694.

26. Malnick S, Bardenstein R, Huszar M, Gabbay J, Borkow G (2008) Pyjamas and sheets as a potential source of nosocomial pathogens. J Hosp Infect 70(1): 89-92.

27. Fijan S, Turk SS (2012) Hospital textiles, are they a possible vehicle for healthcare-associated infections? Int J Environ Res Public Health 9(9): 3330-3343.

28. Borkow G, Gabbay J (2008) Biocidal textiles can help fight nosocomial infections. Med Hypotheses 70(5): 990-994.

29. Borkow G (2014) Biocidal hard and soft surfaces containing copper oxide particles for the reduction of healthcare-acquired pathogens. Use of Biocidal Surfaces for Reduction of Healthcare Acquired Infections 1(5): 85-101.

30. Neely AN, Maley MP (2000) Survival of enterococci and staphylococci on hospital fabrics and plastic. J Clin Microbiol 38(2): 724-726.

31. Neely AN, Orloff MM (2001) Survival of some medically important fungi on hospital fabrics and plastics. J Clin Microbiol 39(9): 3360-3361.

32. Wiener-Well Y, Galuty M, Rudensky B, Schlesinger Y, Attias D, et al. (2011) Nursing and physician attire as possible source of nosocomial infections. Am J Infect Control 39(7): 555-559. 


\section{Journal of Infectious Diseases \& Travel Medicine}

33. Kramer A, Assadian O (2014) Survival of microorganisms on inanimate surfaces. Use of Biocidal Surfaces for Reduction of Healthcare Acquired Infections 2: 7-26.

34. Koca O, Altoparlak U, Ayyildiz A, Kaynar H (2012) Persistence of nosocomial pathogens on various fabrics. Eurasian J Med 44(1): 28-31.

35. Shiomori T, Miyamoto $H$, Makishima K, Yoshida $M$, Fujiyoshi T, et al. (2002) Evaluation of bedmakingrelated airborne and surface methicillin-resistant Staphylococcus aureus contamination. J Hosp Infect 50(1): 30-35.

36. Handorean A, Robertson CE, Harris JK, Frank D, Hull $\mathrm{N}$, et al. (2015) Microbial aerosol liberation from soiled textiles isolated during routine residuals handling in a modern health care setting. Microbiome 3: 72 .

37. McQueen RH, Ehnes B (2017) Antimicrobial textiles and infection prevention: clothing and the inanimate environment. Infection Prevention 13: 117-126.

38. Mitchell A, Spencer M, Edmiston C (2015) Role of healthcare apparel and other healthcare textiles in the transmission of pathogens: a review of the literature. J Hosp Infect 90(4): 285-292.

39. Lazary A, Weinberg I, Vatine JJ, Jefidoff A, Bardenstein $\mathrm{R}$, et al. (2014) Reduction of healthcare-associated infections in a long-term care brain injury ward by replacing regular linens with biocidal copper oxide impregnated linens. Int J Infect Dis 24: 23-29.

40. Renaud FNR, Dore J, Freney HJ, Coronel B, Dusseau JY (2006) Evaluation of antibacterial properties of a textile product with antimicrobial finish in a hospital environment. Journal of Industrial Textiles 36(1): 8994.

41. Openshaw JJ, Morris WM, Lowry GV, Nazmi A (2016) Reduction in bacterial contamination of hospital textiles by a novel silver-based laundry treatment. Am J Infect Control 44(12): 1705-1708.

42. Argirova M, Leseva M, Perelshtein I, Gedanken A, Genchev EG (2017) Antimicrobial medical textile - an important part of the complex infection control measures in the burn units. Sch J Emerg Med Crit Care 1(2): 42-52.

43. Bearman GM, Rosato A, Elam K, Sanogo K, Stevens MP, et al. (2012) A crossover trial of antimicrobial scrubs to reduce methicillin-resistant Staphylococcus aureus burden on healthcare worker apparel. Infect Control Hosp Epidemiol 33(3): 268-275.

44. Butler JP (2018) Effect of copper-impregnated composite bed linens and patient gowns on healthcare-associated infection rates in six hospitals. J Hosp Infect 100(3): 130-134.

45. Marcus EL, Yosef H, Borkow G, Caine Y, Sasson A, et al. (2017) Reduction of health care-associated infection indicators by copper oxide-impregnated textiles: Crossover, double-blind controlled study in chronic ventilator-dependent patients. Am J Infect Control 45(4): 401-403.

46. Madden GR, Heon BE, Sifri CD (2018) Effect of copper-impregnated linens on multidrug-resistant organism acquisition and Clostridium difficile infection at a long-term acute-care hospital. Infect Control Hosp Epidemiol 39(11): 1384-1386.

47. Burke GH, Butler JP (2018) Analysis of the role of copper impregnated composite hard surfaces, bed linens and patient gowns in reducing healthcareassociated infection rate. Int J Infect Control 14(1): 18.

48. Arendsen L, Thakar R, Sultan A (2019) The impact of copper impregnated wound dressings on surgical site infection following caesarean section: a double blind randomised controlled study. Eur J Obstet Gynec Reprod Bio 234: 171.

49. Arendsen L, Thakar R, Sultan A (2019) Can perineal wound infection following vagina delivery be reduced? A double blind randomised controlled trial using copper impregnated maternity sanitary towels. Eur J Obstet Gynec Reprod Bio 234: 180. 